\title{
Studies on the Effect of Different Insecticidal Applications on Quality, Nutritional Parameters and Total Antioxidant Capacity of Brinjal (Solanum melongena L.)
}

\author{
Moumit Roy Goswami ${ }^{1 a}$, Ujjal Kumar Pati ${ }^{2 b^{*}}$, Puja Maity ${ }^{3 c}$ \\ and Aniruddha Mukhopadhyay ${ }^{3 \mathrm{~d}}$ \\ ${ }^{1}$ Department of Environmental Science, Netaji Nagar College for Women, 170/13/1 N.S.C Bose \\ Road, Regent Estate, Kolkata-700092, India \\ ${ }^{2}$ Department of Agricultural Chemistry and Soil Science, Institute of Agricultural Science, University \\ of Calcutta, 35 Ballygunj Circular Road, Kolkata-700019, West Bengal, India \\ ${ }^{3}$ Department of Environmental Science, University of Calcutta, 35 Ballygunj Circular Road, \\ Kolkata-700019, West Bengal, India \\ amoumit417@gmail.com, b' bujjalkrpati@gmail.com, cpujam3440@gmail.com, \\ damcu.envs24@gmail.com
}

Keywords: Brinjal, Insecticides, Fruit quality and nutritional parameters, Total antioxidant capacity.

\begin{abstract}
Brinjal (Solanum melongena L.) suffers from the attack of various pests throughout its different stages of the crop growth. Different insecticides are used to control these pest infestations. The application of these insecticides on brinjal plants may have an effect on their quality and nutritional parameters of fruit samples. In the present study effect of three different insecticides viz. Triazophos 40\% E.C. Carbaryl 50\% W.D.P, Cypermethrin 10\% E.C. and Azadiractin 10,000 ppm formulation belonging to different groups namely organophosphate, carbamate, synthetic pyrethroids and botanical insecticide on brinjal fruit quality, nutritional parameters and total antioxidant capacity (TAC) were assessed in field conditions. The results showed that different insecticides at field application dose showed minute insignificant variation in fruit nutritional and total antioxidant activity parameters in comparison to the control samples. The fruit quality parameters also showed minute variation in comparison to the control, except in the case of Triazophos treated samples which showed significant variation $(p<0.05)$ in total soluble sugar content and crude protein.
\end{abstract}

\section{Introduction}

The nutritional features and antioxidant activity of fruits and vegetables are highly beneficial to health as they protect against cellular level oxidation reactions. The beneficial effect of fruits and vegetables are mostly dependent on quantity of numerous antioxidants [1-5]. The fruit quality parameters considered are soluble solids content, titratable acidity etc. while the nutritional parameters are total phenolic content and flavonoid content and Total Antioxidant Capacity (TAC) in terms of 1,1-diphenyl-2-picrylhydrazyl (DPPH) assay, reducing power and hydroxyl radical scavenging activity. The oblong-fruited brinjal cultivars are rich in total soluble sugars, while free reducing sugars, anthocyanins, phenols, glycoalkaloids content were higher in long fruited cultivators. Cao et al. [6] reported that brinjal has high oxygen radical absorbance capacity due to its phenolic content. Brinjal, is cultivated in India, as an important cash crop by farmers. The Indian scenario of cultivation of brinjal depicts that brinjal is cultivated over an area of more than 5,00,000 ha [7] and henceforth is a key source of cash for many farmers [8]. The average yield of brinjal in India has been reported to be around 200 to 350 quintals per ha [7]. Apart from the attack of various insect pest throughout the cropping season of brinjal, the biggest threat to brinjal cultivation in India is the widespread infestation of brinjal or eggplant by eggplant shoot and fruit borer (ESFB), which can damage $95 \%$ of the crop, during the rainy season [9]. To protect their crop, farmers have been 
relying on insecticides, because alternative control measures have not been well developed [10]. The use of these pesticides on brinjal plants may have an effect on their quality and nutritional parameters. Pesticides have been earlier reported to affect the content of acids, sugars, and possibly other constituents, that might affect flavor [11, 12]. Tichneor et al. [13] studied the effect of 21 insecticides and five fungicides on strawberry. They found no off flavors in the frozen fruit that could be related to pesticide treatment. Murphy et al. [14] reported that thiodan has no effect on strawberry quality. Sweeney et al. [15] studied the effect of chlordan, demeton, captan and ferbam on quality of strawberry at their recommended dose of application. They reported little detectable effect on compositional factors, including sugars and acids, or on color, texture and flavor of fruit. They also reported no relationship between residue levels and quality of strawberries. Habiba et al. [16] reported that profenofos increased the percent protein content in potatoes. It is also reported that pirimiphos-methyl residues showed adverse effect on the content of total soluble sugars in tomato fruit and broad bean seeds [17]. Bertin et al. [18] reported non-significant reduction in titrtatable acidity content in carbaryl treated fruit samples. Radwan et al. [19] reported that residues of profenofos and pirimiphos-methyl, increased ascorbic acid content and decreased total soluble sugars, percent acidity and total suspended solids (TSS) content of brinjal/eggplant fruit. The present endevour was therefore initiated to study the effect of four different insecticides application on quality, nutritional parameters and total antioxidant capacity of brinjal fruit samples collected from field conditions.

\section{Materials and Methods}

The experiment was in rabi season (November-March) of 2009-10 at Experimental Farm of University of Calcutta, Baruipur, (22 $22^{\circ} 44.20^{\prime}$ N $86^{0} 26^{\prime} 08.55^{\prime}$ E) South 24 Parganas, West Bengal, India, in a Randomized Block Design (RBD) with 20 plots (measuring $4 \times 3 \mathrm{~m}^{2}$ ), involving four different insecticidal treatments and control with each application plot having four replications. Brinjal variety (var. Muktakeshi) was used in the experiment.

The insecticides chosen for the study were purchased from local agro market and applied to the crops at recommended doses of field application. The treatment/dose details were Triazophos (3-(o,o-diethyl)-1-phenyl thiophosphoryl- 1,2,4-triazol) 40\% EC (300 g.a.i/ha), Cypermethrin (RS)alpha-cyano-3-phenoxybenzyl(1RS)-cis,trans-3-(2,2-dichlorovinyl)-2,2-dimethyl cyclopropanecarboxylate) 10\% EC (60 g.a.i/ha), Carbaryl (1- naphthalenyl methylcarbamate) $50 \%$ WDP (1875 g.a.i/ha) and Azadirachtin 10000 ppm (5 g.a.i/ha). The conversion of the field application rate was made accordingly to the area of the plots $\left(4 \times 3 \mathrm{~m}^{2}\right)$. Insecticidal sprays were applied using a pressurized knapsack sprayer fitted with a single-cone nozzle at the rate of $500 \mathrm{~L} / \mathrm{ha}$. The spray dose was also calculated taking in consideration the area of the plots. The control plots received water treatment only. The insecticides were applied at an interval of 15 days following the pest attack, up to a threshold level to harvesting. In order to evaluate the effect of different insecticidal applications on brinjal fruit, analytical determinations of brinjal fruit quality, nutritional and total antioxidant parameters were made on both insecticide treated and untreated fruits. Fully mature brinjal fruits were picked 15 days after last application of insecticides. All the brinjal fruits used in the study were approximately of the same size, the same degree of maturity and not infested by pests.

\section{Fruit quality parameters}

\section{Total soluble solids (TSS)}

Brinjal fruit samples were taken for juice extraction and total soluble solids of the juice was determined by using a hand refractometer [20]. TSS was expressed in ${ }^{0}$ Brix.

\section{Titratable acidity (TA)}

The juice from brinjal fruit samples was extracted from $5 \mathrm{~g}$ of brinjal fruit sample and filtered through muslin cloth. The volume was made up to $25 \mathrm{ml}$ with distilled water. The mixture was then 
titrated against standard $\mathrm{NaOH}$, using phenolphthalein as an indicator. The appearance of light pink color was recorded at the end point. The result was expressed in terms of per cent acidity of the fruit [20].

\section{Total soluble sugars}

Total soluble sugars were measured following the method of Dubois et al. [21] with some The

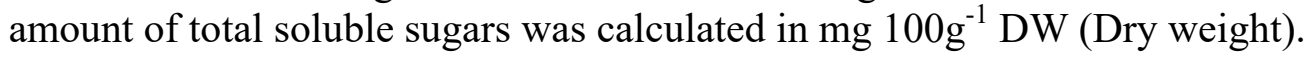

\section{Crude protein}

The crude protein was determined using micro Kjeldahl method as described in AOAC [22] with certain modifications. The crude protein content of the brinjal fruit samples was estimated by multiplying the percentage of nitrogen content by a factor of 6.25 .

\section{Fruit Nutritional parameters}

The brinjal fruit samples collected from both insecticide treated and control field were washed thoroughly in tap water to remove adhering mud particles, rinsed in distilled water, drained, and dried in a hot air oven at $50^{\circ} \mathrm{C}$. The dried fruits were finely powdered. The dried powder was extracted in $100 \mathrm{ml}$ of $(80: 20)$ methanol and distilled water in a shaker for 8 hrs. The extract was decanted and extraction was repeated with fresh 80:20 methanol-water until the extract was colorless. The extracts were pooled and evaporated in a rotary evaporator below $40^{\circ} \mathrm{C}$ till the extract was free of the solvent.

\section{Total polyphenol content}

Total polyphenol content of brinjal fruit extract was determined by a method described by Matthaus [23] with certain modifications. The concentration was calculated using gallic acid as a standard, and the results were expressed as gallic acid equivalents (mg GAE) $\mathrm{g}^{-1}$ extract.

\section{Total flavonoid content}

The total flavonoid content was determined by using the method of Lamien et al. [24] with certain modifications. Total flavonoid content was expressed as $\mathrm{mg}$ of quercetin equivalents (QAE) $\mathrm{g}^{-1}$ extract.

\section{Ascorbic acid content}

Ascorbic acid content of brinjal fruit samples was determined according to 2, 6dichlorophenolindophenol dye method [25]. Results were expressed as $\mathrm{mg} 100 \mathrm{~g}^{-1} \mathrm{FW}$ (Fresh weight).

\section{Total antioxidant activity (TAC) \\ DPPH Assay}

The free radical scavenging activity of methanol extracts of brinjal was measured by diphenyl- $\beta-\alpha-\alpha$-picryl-hydrazyl (DPPH) using the method described by Oktay et al. [26]. $0.1 \mathrm{mmol}$ $1^{-1}$ solution of DPPH in methanol was prepared and $1 \mathrm{ml}$ of this solution was added to $3 \mathrm{ml}$ of brinjal fruit extracts solution at concentrations of $50 \mu \mathrm{g}$. After $30 \mathrm{~min}$ absorbance (A) was measured at $517 \mathrm{~nm}$. Lower absorbance of the reaction mixture indicated higher free radical scavenging activity. Radical scavenging activity was expressed as inhibition percentage and was calculated using the formula.

$$
\text { Radical Scavenging Activity }(\%)=\frac{(\text { Control A }- \text { Sample A })}{\text { Control A }} \times 100
$$

\section{Reducing power}

The reducing power of brinjal fruit was determined according to the method of Oyaizu [27]. Brinjal fruit extract $(50 \mu \mathrm{g})$ in $1 \mathrm{ml}$ of distilled water was mixed with phosphate buffer $(2.5 \mathrm{ml}, 0.2$ $\mathrm{mol} / \mathrm{l}, \mathrm{pH}$ 6.6) and potassium ferricyanide $\mathrm{K}_{3} \mathrm{Fe}(\mathrm{CN})_{6}(2.5 \mathrm{ml}, 1 \%)$. The mixture was incubated at 
$50^{0} \mathrm{C}$ for $20 \mathrm{~min}$. A portion $(2.5 \mathrm{ml})$ of trichloroacetic acid $(10 \%)$ was added to the mixture, which was then centrifuged at $300 \mathrm{rpm}$ for $10 \mathrm{~min}$. The upper layer of the solution $(2.5 \mathrm{ml})$ was mixed with distilled water $(2.5 \mathrm{ml})$ and $\mathrm{FeCl}_{3}(0.5 \mathrm{ml}, 0.1 \%)$ the absorbance was measured at $700 \mathrm{~nm}$. Increased absorbance of the reaction mixture indicated increased reducing power.

\section{Hydroxyl radical scavenging activity}

The hydroxyl radical scavenging activity was determined according to the methods described by Singh et al. [28]. The absorbance of the yellow colour formed was measured spectrophotometrically at $412 \mathrm{~nm}$ against reagent blank. The percentage hydroxyl radical scavenging activity was calculated by the following formula,

$$
\text { Hydroxyl Radical Scavenging Activity (\%) = } 1-\frac{\text { Absorbance of Sample }}{\text { Absorbance of Blank }} \times 100
$$

\section{Statistical analysis}

Treatments were replicated three times in a completely randomized design. Analysis of variance (ANOVA) followed by post-hoc Test Duncan's multiple range test (DMRT) were applied to evaluate homogeneity or differences between the treatments using SPSS (Version 21.0) statistical software package. Differences obtained at a level of $\mathrm{P}<0.05$ were considered significant.

\section{Results and Discussion}

The results showing the effect of insecticidal applications on brinjal fruit quality are represented in Table-1. The result shows that the change in total TSS content of all the insecticide treated samples was found to be not statistically significantly different $(p<0.05)$, in comparison to the control. The maximum TSS content of $3.21^{0}$ Brix was found in azadirachtin and cypermethrin treated sample, while minimum of $3.08^{0} \mathrm{Brix}$ was found in case of triazophos treated samples. The total soluble sugar content was significantly $(\mathrm{p}<0.05)$ reduced in triazophos treated samples, in comparison to the control. Similar results were obtained by Radwan et al. [19] who reported that residues of profenofos, an organophosphate insecticide reduced the total soluble sugar content of eggplant fruit. Azadirachtin and cypermethrin treated fruit samples showed a non-significant increase, when compared to the control samples, while carbaryl treated fruit samples showed a decrease in the total soluble sugar content, but the decrease was found to be non-significant. Little [29] reported that sugars constitute $98.8 \%$ of the TSS content of fruits. It is noteworthy to mention here that the TSS content of the only triazophos treated fruit samples were found to be less than the control samples, since the total soluble sugar content in triazophos treated fruits was found to significantly $(p<0.05)$ less than the control. Interestingly, in all the other insecticides treated fruit samples though the increase or decrease in the TSS content of the fruit are found to be nonsignificant, but the increase or decrease in the TSS content in fruit samples followed the same trend, as in the case of total soluble sugars. The titratable acidity of fruits of azadirachtin and cypermethrin treated samples were found to be highest (i.e. $0.42 \%$ ) amongst the treatments, but in comparison to control the increase in titratable acidity was non-significant. Carbaryl and triazophos treated fruit samples showed lesser titratable acidity content than the control. The more pronounce decrease in titratable acidity in triazophos treated fruit samples could be linked up to TSS and sugar content. Capocasa et al. [30] have reported significant correlation between TSS content and titratable acidity content in strawberries. It has also been reported that organic acids are produced in the fruit itself from stored carbohydrates [31]. The reduction in titratable acidity content in carbaryl treated samples was not significant, as in other cases. Teskey and Kung [32] reported that the carbaryl application in apple cultivation also did not influence the level of acids in apples. The crude protein content of azadirachtin, cypermethrin and carbaryl treated fruit samples was found to be nonsignificant in comparison to the control. However, in case of triazophos treated fruit samples it was found to be significantly $(\mathrm{p}<0.05)$ different. 
Table 1. Effect of different insecticidal treatments on brinjal fruit quality parameters.

\begin{tabular}{|c|c|c|c|c|}
\hline \multirow{2}{*}{ Treatments } & \multicolumn{4}{|c|}{ Fruit quality parameters } \\
\cline { 2 - 5 } & $\begin{array}{c}\text { TSS } \\
\left.\text { (in }{ }^{\mathbf{0}} \text { Brix }\right)\end{array}$ & $\begin{array}{c}\text { Titratable acidity } \\
\text { (\% acidity) }\end{array}$ & $\begin{array}{c}\text { Total soluble } \\
\text { sugars } \\
\left(\mathbf{m g} / \mathbf{1 0 0 g} \mathbf{D . W} .^{*}\right)\end{array}$ & $\begin{array}{c}\text { Crude Protein } \\
\text { (\% protein) }\end{array}$ \\
\hline Control & $3.17^{\mathrm{a}^{*}}$ & $0.41^{\mathrm{a}}$ & $11.79^{\mathrm{a}}$ & $1.52^{\mathrm{a}}$ \\
\hline Azadiractin 10000 ppm & $3.21^{\mathrm{a}}$ & $0.42^{\mathrm{a}}$ & $11.82^{\mathrm{a}}$ & $1.54^{\mathrm{a}}$ \\
\hline Triazophos 40\% E.C & $3.08^{\mathrm{a}}$ & $0.40^{\mathrm{a}}$ & $11.39^{\mathrm{b}}$ & $1.59^{\mathrm{b}}$ \\
\hline Carbaryl 50\% W.D.P & $3.19^{\mathrm{a}}$ & $0.40^{\mathrm{a}}$ & $11.72^{\mathrm{a}}$ & $1.53^{\mathrm{a}}$ \\
\hline Cypermethrin 10\% E.C & $3.21^{\mathrm{a}}$ & $0.42^{\mathrm{a}}$ & $11.82^{\mathrm{a}}$ & $1.53^{\mathrm{a}}$ \\
\hline
\end{tabular}

Data are mean values of three replicates; *Means within a column followed by the same alphabetical letters are not significantly different at $\mathrm{p} \leq 0.05$ by DMRT. $*$ D.W. $=$ Dry Weight.

The results showing the effect of different insecticidal applications on brinjal fruit nutritional and total antioxidant capacity parameters are represented in Table 2-3. The result shows that the total polyphenol content of the brinjal fruit samples collected from different insecticidal treatment plots were found to be statistically at par with the control at 5\% level of significance. Maximum polyphenol content was found in azadirachtin treated fruit sample (i.e. $3.7 \mathrm{mg} \mathrm{GAE} \mathrm{g}^{-1}$ extract), while minimum was obtained in triazophos treated samples (i.e. $3.3 \mathrm{mg} \mathrm{GAE} \mathrm{g}^{-1}$ extract). Van Acker et al. [33] have reported that phenols and polyphenolic compounds, such as flavonoids found widely in food products derived from plant sources possess significant antioxidant activities. The flavonoid content also showed similar trend, in increase or decrease, as that of polyphenolic content. The change in flavonoid content in the insecticide treated samples were also nonsignificant at 5\% level of significance in comparison to control. Maximum flavonoid content was found in azadirachtin treated fruit samples (i.e. $0.24 \mathrm{mg} \mathrm{QAE} \mathrm{g}^{-1}$ extract) which accounted for 20.83 percent increase over control samples. Though there is no significant $(p<0.05)$ variation in ascorbic acid content within the treatments, ascorbic acid (vitamin $\mathrm{C}$ ) content was also found to be maximum in the azadirachtin treated samples (i.e. $5.11 \mathrm{mg} 100 \mathrm{~g}^{-1}$ F.W) while the minimum ascorbic acid content of fruits was found in triazophos treated samples (i.e. $5.01 \mathrm{mg} 100 \mathrm{~g}^{-1} \mathrm{~F}$.W).

Table 2. Effect of different insecticidal treatments on brinjal fruit nutritional parameters.

\begin{tabular}{|c|c|c|c|}
\hline \multirow{2}{*}{ Treatments } & \multicolumn{3}{|c|}{ Fruit nutritional parameters } \\
\hline & $\begin{array}{l}\text { Total Polyphenol } \\
\text { content (**mg GAE } \\
\mathrm{g}^{-1} \text { extract) }\end{array}$ & 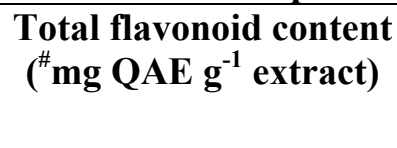 & $\begin{array}{l}\text { Ascorbic acid content } \\
\left(\mathrm{mg} \mathbf{1 0 0 g}^{-1} \text { F.W. }{ }^{*}\right)\end{array}$ \\
\hline Control & $3.4^{\mathrm{a}}$ & $0.20^{\mathrm{a}}$ & $5.03^{\mathrm{a}}$ \\
\hline Azadiractin $10000 \mathrm{ppm}$ & $3.7^{\mathrm{a}}$ & $0.24^{\mathrm{a}}$ & $5.11^{\mathrm{a}}$ \\
\hline Triazophos $40 \%$ E.C & $3.3^{\mathrm{a}}$ & $0.18^{\mathrm{a}}$ & $5.01^{\mathrm{a}}$ \\
\hline Carbaryl 50\% W.D.P & $3.4^{\mathrm{a}}$ & $0.19^{\mathrm{a}}$ & $5.03^{\mathrm{a}}$ \\
\hline Cypermethrin 10\% E.C & $3.6^{\mathrm{a}}$ & $0.22^{\mathrm{a}}$ & $5.04^{\mathrm{a}}$ \\
\hline
\end{tabular}

Data are mean values of three replicates; *Means within a column followed same alphabetical letters are not significantly different at $\mathrm{p} \leq 0.05$ by DMRT. ${ }^{*} \mathrm{~F} . \mathrm{W} .=$ Fresh Weight. ${ }^{*} \mathrm{mg}$ GAE/g extract $=\mathrm{mg}$ of gallic acid equivalents / g extract,

\#mg QAE/g extract=mg of quercetin equivalents/g extract. 
Table 3. Effect of different insecticidal treatments on brinjal fruit total antioxidant activity.

\begin{tabular}{|l|c|c|c|}
\hline \multirow{2}{*}{ Treatments } & \multicolumn{3}{|c|}{ Total antioxidant activity(TAC) } \\
\cline { 2 - 4 } & $\begin{array}{c}\text { DPPH assay } \\
\text { \% Radical Scavenging } \\
\text { Activity }\end{array}$ & $\begin{array}{c}\text { \% Hydroxyl Radical } \\
\text { Scavenging activity }\end{array}$ & Reducing power \\
\hline Control & $20.6^{\mathrm{a}^{*}}$ & $24.8^{\mathrm{a}}$ & $0.887^{\mathrm{a}}$ \\
\hline Azadiractin 10000 ppm & $21.5^{\mathrm{a}}$ & $25.3^{\mathrm{a}}$ & $0.891^{\mathrm{a}}$ \\
\hline Triazophos 40\% E.C & $20.5^{\mathrm{a}}$ & $24.7^{\mathrm{a}}$ & $0.886^{\mathrm{a}}$ \\
\hline Carbaryl 50\% W.D.P & $20.9^{\mathrm{a}}$ & $24.9^{\mathrm{a}}$ & $0.888^{\mathrm{a}}$ \\
\hline Cypermethrin 10\% E.C & $21.2^{\mathrm{a}}$ & $25.0^{\mathrm{a}}$ & $0.889^{\mathrm{a}}$ \\
\hline
\end{tabular}

Data are mean values of three replicates; $*$ Means within a column followed by the same alphabetical letters are not significantly different at $\mathrm{p} \leq 0.05$ by DMRT.

Reports existing in literature shows a high correlation between phenolic content and antioxidant activity of various fruit and vegetables [34-40]. Flavonols such as quercetin and flavones in plant materials are also closely associated with their antioxidant function mainly due to their redox properties employed by various possible mechanisms including free-radical scavenging activity, transition-metal-chelating activity, and/or singlet oxygen- quenching capacity [41-42]. Shyamala et al. [43] observed a high positive correlation $(\mathrm{r}=0.88)$ between the polyphenol content and hydroxyl radical scavenging activity. Antioxidant effect exponentially increases as a function of the development of the reducing power, indicating that the antioxidant is associated with the development of reducing power [44]. In the present study, hydroxyl radical scavenging and reducing power of brinjal fruit extracts at concentration of $50 \mu \mathrm{g} \mathrm{ml}^{-1}$ in case of all the treatments and the control were statistically par at 5\% level of significance as determined by Duncan's Multiple range test (DMRT). Studies on the fruits and vegetables have revealed a linear correlation between the DPPH scavenging activity and polyphenol content [45, 46]. The free radical scavenging activity of brinjal fruit extracts as measured by DPPH assay also showed no significant $(p<0.05)$ variation between the treatments and the control. An interesting observation here is that though in carbaryl treated samples, the total polyphenolic content was same and the flavinoid content was less than the control samples, yet the free radical scavenging activity and hydroxyl radical scavenging activity were found to be marginally increased in carbaryl treated samples than control samples. This may because of the fact the ascorbic acid (vitamin C) content of carbaryl treated fruits were slightly more than the control samples. It has reported that the total antioxidant activity in strawberries mainly depends on vitamin $\mathrm{C}$ content along with polyphenols, flavonoid and anthocyanin $[47,48]$. The results therfore reveals that samples with more ascorbic acid (vitamin C), polyphenolic or flavonoid content show more antioxidant capacity, but the variation in nutritional parameters and total antioxidant activity of brinjal fruit samples from insecticide treated plots were found to be nonsignificant.

\section{Conclusion}

Therefore, the study reveals that following insecticidal application at field application dose on brinjal, showed minor changes in fruit quality, nutritional parameters and total antioxidant capacity of brinjal fruit samples and in most of the cases the changes were found to be nonsignificant amongst the treatments. However, in the case of triazophos treated samples, a significant variation in total soluble sugar content and crude protein were obtained.

\section{Conflict of Interest}

The authors declare that there is no conflict of interest. 


\section{References}

[1] D. Steinberg, Beyond cholesterol: modifications of low-density lipoprotein that increase its atherogenicity, New England J. Med. 320 (1989) 915-924.

[2] B.M. Ames, M.K. Shigens, T.M. Hagen, Oxidants, antioxidants and the degenerative diseases of aging, Proc. Nat. Acad. Sci. 90 (1993) 7915-7922.

[3] N.C. Cook, S. Samman, Flavonoids - chemistry, metabolism, cardioprotective effects, and dietary sources, J. Nut. Biochem. 7(2) (1996) 66-76.

[4] J.H. Cohen, A.R. Kristal, J.L. Stanford, Fruit and vegetable intakes and prostate cancer risk, J. Nat. Can. Inst. 92 (2000) 61-68.

[5] B.L. Halvorsen et al., A systematic screening of total antioxidants in dietary plants, J. Nut. 132 (2002) 461-471.

[6] G.H. Cao, E. Sofic, R.L. Prior, Antioxidant capacity of tea and common vegetables. J. Agric. Food Chem. 44 (1996) 3426-3431.

[7] K. Elanchezhyan, R.K.B Murali, D. S Rajavel, Field screening of brinjal varieties on major pests and their natural enemies, J. Biopest. 1(2) (2008) 113-120.

[8] D. Miller, Genetically engineered eggplant, Span. XLVIII (2007) 41.

[9] D.P. Abrol, J.B. Singh, Relative efficacy of some insecticides against brinjal fruit and shoot borer, Leucinodes orbonalis Guen., and their impact on fruit yield, J. Asia-Pac. Ent. 6(1) (2003) 83-90.

[10] S.N. Alam et al., Control of eggplant fruit and shoot borer in South Asia. Technical Bulletin. 36, AVRDC - The World Vegetable Center, Shanhua, Taiwan, 2006.

[11] E.J. Deszyck, R.C.J. Koo, S.V. Ting, Effect of potash on yield and quality of 'Hamlin' and 'Valencia' orange, Proc. Soil Crop Sci. 18 (1958) 129-135.

[12] K.E. Lawyer, R.E. Hartz, Effect of sprays on quality factors of raw red tart cherries, Food Technology. 19(3) (1965) 100-103.

[13] D.A. Tichenor, J.G. Rodriguez, C. E. Chaplin, Effects of certain pesticides on flavour of frozen strawberries, Food Technol. 13(10) (1959) 587-590.

[14] E.F. Murphy et al., Pesticides and food flavor, effect of insecticides and fungicides on the flavor quality of fruits and vegetables, J. Agric. Food Chem. 214 (1961).

[15] J.P. Sweeny, V.J. Chapman, P.A. Hepner, Effect of selected pesticides on quality of strawberries, Journal of Agricultural and Food Chemistry. 16(4) (1968) 632-634.

[16] R.A. Habiba, H.M. Ali, S.M.M. Ismail, Biochemical effects of profenofos residue in potatoes, J. Agric. Food Chem. 40 (1992) 1852-1855.

[17] M.A. Radwan et al., Residue levels of pirimiphos-methyl and cholrifyrifos-methyl on tomato and faba beans plant in relation to their impact on some internal quality parameters, Alex. Sci. Exch. 16(3) (1995) 389-404.

[18] N. Bertin et al., Seasonal evolution the quality of fresh glasshouse tomato under Mediterranean conditions, as affected by vapour pressure deficit and plant fruit load, Ann. Bot. 85 (2000) 741-750.

[19] M.A. Radwan et al., Residue of pirimiphos-methyl and profenofos on green pepper and eggplant fruits and their effect on some quality parameters, Emirates J. Agric. Sci. 16(1) (2004) 32-42.

[20] Anonymous, Official methods of analysis. Association of official analytical chemists, Washington, D. C. 11/e., 1970. 
[21] M. Dubois et al., Colorimetric method for determination of sugars and related substances, Anal. Chem. 28 (1956) 350-356.

[22] AOAC, Official methods of analysis of the association of the analytical chemists, 17th Ed., Inc. Virginia, USA, 2000.

[23] B. Matthaus, Antioxidant activity of extracts obtained from residues of different oilseeds, J. Agric. Food Chem. 50 (2002) 3444-3452.

[24] C.E. Lamien et al., Inhibition of fowlpox virus by an aqueous acetone acetone extract from galls of Guiera senegalensis J. F. Gmel (Combretaceae), J. Etnopharmacol. 96(1-2) (2005) 249-253.

[25] S. Ranganna, Handbook of analysis and quality control for fruits and vegetables products, 2nd ed., Tata Mc Graw Hill Publishing Company Ltd., New Delhi, 1997.

[26] M. Oktay, I. Culcin, O.I. Kufrevioglu, Determination of in vitro antioxidant activity of fennel (Foeniculum vulgare) seed extracts, Lebensmittel-Wissenschaft und-Technologie. 36 (2003) 263-271.

[27] M. Oyaizu, Studies on product of browning reaction prepared from glucose amine, Japan. J. Nut. 44 (1986) 307-315.

[28] R.P. Singh, C.K.N. Murthy, G.K. Jayaprakash, Studies on the antioxidant acitivity of pomegranate (Pubica granatum) peel and seed extract using in vitro models, J. Agric. Food Chem. 50 (2002) 81-86.

[29] C. Little, Apple and pear maturity manual, Colin R. Little, Sherbrooke, Victoria, Australia, 1999.

[30] F. Capocasa et al., Combining quality and antioxidant attributes in the strawberry: The role of genotype, Food Chem. 111 (2008) 872-878.

[31] R. Sakiyama, M.A. Stevens, Organic acid accumulation in attached and detached tomato fruits, J. Am. Soc. Hort. Sci. 101 (1976) 394.

[32] B.J.E. Teskey, S.D. Kung, Some effects of carbaryl on two apple cultivares, Can. J. Plant Sci. 47(3) (1967) 311-318.

[33] S.A. Van Acker et al., Structural aspects of antioxidant activity of flavonoids, Free Rad. Biol. Med. 20(3) (1996) 331-342.

[34] Y. Kiselova et al., Correlation between the in vitro antioxidant activity and polyphenol content of aqueous extracts from Bulgarian herbs, Phytother. Res. 20(11) (2006) 961-965.

[35] I. Klimczak et al., Effect of storage on the content of polyphenols, vitamin $\mathrm{C}$ and the antioxidant activity of orange juices, J. Food Compost Ann. 20 (2007) 313-322.

[36] G.K. Jayaprakasha, B. Girennavar, B.S. Patil, Radical scavenging activities of Rio Red grapefruits and Sour orange fruit extracts in different in vitro model systems, Bio Resource Tech. 99(10) (2008) 4484-4494.

[37] C. Vasco, J. Ruales, A. Kamal-Eldin, Total phenolic compounds and antioxidant capacities of major fruits from Ecuador, Food Chem. 111(4) (2008) 816-823.

[38] S.A. Sheikh et al., Phenolic contents and antioxidants activities in jamman fruit (Eugenia jambolana) products, J. Pharm. Nut. Sci. 1(1) (2011) 41-47.

[39] S. Gorinstein et al., Antioxidative properties of Jaffa sweeties and grapefruit and their influence on lipid metabolism and plasma antioxidative potential in rats, Biosci. Biotech. Biochem. 67(4) (2003) 907-910. 
[40] F.D. Benmeziane, R. Djamai, Y. Cadot, Antioxidant capacity, total phenolic, carotenoid, and vitamin c contents of five table grape varieties from Algeria and their correlations, J. Int. Sci. Vigne Vin. 48 (2014) 153-162.

[41] S.B. Lotito, B. Frei, Consumption of flavonoid-rich foods and increased plasma antioxidant capacity in humans: Cause, consequence, or epiphenomenon? Free Rad. Biol. Med. 41(12) (2006) 1727-1746.

[42] H. Kappus, Lipid peroxidation - Mechanism and biological relevance, in: Free Radicals and Food Additives, O. I. Aruoma, B. Halliwell (Eds.), Taylor and Francis, New York, 1991, pp. $59-75$.

[43] B. N. Shyamala et al., Leafy vegetables extracts- Antioxidant activity and effect on storage stability of heated oils, Innov. Food Sci. Emerging Technol. 6(2) (2005) 239-245.

[44] M. Tanaka et al., Applications of antioxidative Maillard reaction products from histidine and glucose to sardine products, Nippon Suisan Gakkaishi. 54 (1988) 1409-1414.

[45] K. Robards et al., Phenolic compounds and their role in oxidative processes in fruits, Food Chem. 66 (1999) 401-436.

[46] O.E. Adebiyi et al., In vitro antioxidant activity, total phenolic and flavonoid contents of ethanol extract of stem and leaf of Grewia carpinifolia, Beni-Suef University J. Basic and Appl. Sci. 6 (2017) 10-14.

[47] C.J. Guo et al., High performance liquid chromatography coupled with coulometric array detection of electroactive components in fruits and vegetables: Relationship to oxygen radical absorbance capacity, J. Agric. Food Chem. 45 (1997) 1787-1796.

[48] A.R. Proteggente et al., The antioxidant activity of regularly consumed fruit and vegetables reflects their phenolic and vitamin C composition, Free Rad. Res. 36(2) (2002) 217-233. 